\title{
Pengaruh Imbangan Energi dan Protein Ransum Terhadap Pertumbuhan Itik Pitalah Yang Diberi Probiotik Bacillus amyloliquefaciens
}

\section{Effect of The Balance Energy and Protein Ration on the Growth of Pitalah Duck Which is Given Probiotic of Bacillus amyloliquefaciens}

\author{
Zurmiati", Wizna, M. H. Abbas dan M. E. Mahata \\ Fakultas Peternakan Universitas Andalas, Padang, 25163 \\ *E-mail: zurmiatizahyuja@yahoo.com \\ (Diterima: 29 Maret 2017; Disetujui: 31 Mei 2017)
}

\begin{abstract}
ABSTRAK
Penelitian ini bertujuan untuk mengetahui keseimbangan energi dan protein dalam ransum yang disuplementasi dengan probiotik Bacillus amyloliquefaciens terhadap performa itik Pitalah. Pernelitian ini menggunakan Rancangan Acak Kelompok (RAK) pola faktorial 3 × 3 dengan 3 kelompok bobot badan sebagai ulangan. Faktor A adalah level energi yaitu : 2800, 2700, dan $2600 \mathrm{kkal} / \mathrm{kg}$ dan faktor B adalah level protein yaitu: 18,17 , dan $16 \%$. Peubah yang diamati adalah konsumsi ransum, pertambahan bobot badan dan konversi ransum. Hasil penelitian menunjukkan bahwa terdapat interaksi yang berbeda sangat nyata $(\mathrm{P}<0.01)$ antara level energi dan level protein terhadap konsumsi ransum, pertambahan bobot badan, dan konversi ransum. Kesimpulan hasil penelitian ini adalah dengan pemberian probitik Bacillus amyloliquefaciens dapat menurunkan kebutuhan energi ransum itik sebesar $3.57 \%$ dan menurunkan kebutuhan protein sebesar 5.56\% dengan imbangan energi $2700 \mathrm{kkal}$ dan protein $17 \%$ dalam ransum.
\end{abstract}

Kata kunci: Bacillus amyloliquefaciens, itik Pitalah, performa, probiotik, imbangan energi dan protein

\begin{abstract}
The purpose of this study is to determine the balance of energy and protein in the ration which is given probiotic of Bacillus amyloliquefaciens on the performance of Pitalah duck. This experiment was using a group-randomized design with a $3 \times 3$ factorial pattern with three groups of body weight as replications and two factors. Factor A is energy level (2800, 2700, and $2600 \mathrm{kcal} / \mathrm{kg})$, Factor B is protein level $(18,17$, and 16\%). Feed consumption, body weight gain and feed conversion were measured. The results showed that combination of the energy level and the protein level as well as the interaction of both factors are significant $(P<0.01)$ towards feed intake, body weight gain and feed conversion. It can be concluded that the combination of energy and protein with administering Bacillus amyloliquefaciens probiotic can decrease $3.57 \%$ energy needed on duck ration and decrease $5.56 \%$ protein needed with $2700 \mathrm{kcal} / \mathrm{kg}$ energy balance and $18 \%$ protein in the ration.
\end{abstract}

Keywords: Bacillus amyloliquefaciens, performance, Pitalah duck, probiotic, the balance of energy and protein

\section{PENDAHULUAN}

Itik Pitalah merupakan salah satu rumpun itik lokal Indonesia yang mempunyai keseragaman bentuk fisik dan komposisi genetik serta kemampuan adaptasi dengan baik pada keterbatasan lingkungan. Itik Pitalah mempunyai ciri khas yang berbeda dengan rumpun itik asli atau itik lokal lainnya dan merupakan kekayaan sumber daya genetik ternak lokal Indonesia. Berdasarkan Keputusan Mentri Pertanian (2011) bahwa itik Pitalah merupakan salah satu rumpun itik lokal Indonesia yang mempunyai sebaran asli geografi di Provinsi Sumatera Barat, dan telah dibudidayakan secara turun temurun dan merupakan kekayaan sumber daya genetik ternak Indonesia yang perlu dilindungi dan 
dilesterikan. Ternak itik merupakan salah satu jenis unggas potensial setelah ayam (Suharno dan Amri, 2000). Dalam industri perunggasan, penghematan biaya ransum merupakan tujuan yang harus dicapai agar mendapatkan keuntungan yang maksimal. Ransum merupakan salah satu kendala yang dirasakan sebagai beban oleh para peternak, terutama penyediaan bahan ransum yang berkualitas dengan kontinuitas yang terjamin dan harga yang terjangkau.

Informasi tentang kebutuhan zat makanan pada ternak unggas merupakan dasar penting untuk meningkatkan efisiensi ekonomis pemberian ransum. Kebutuhan zat makanan untuk pertumbuhan biasanya dihubungkan dengan jumlah berbagai zat makanan yang dibutuhkan per hari untuk mendukung pertambahan bobot badan ternak secara maksimal. Halpalingmendasar danperlu diketahui adalah kebutuhan serta imbangan akan energi dan protein dalam ransum untuk setiap spesies hewan dan setiap tahapan hidup dari spesies tersebut. Selanjutnya harus ditetapkan efisiensi penggunaan ransum yang menunjang pertumbuhan yang maksimum, dan keseimbangan antara kandungan zatzat makanan seperti asam amino essensial, vitamin-vitamin dan elemen inorganik essensial dalam ransum. Secara ekonomis ransum harus disusun sedemikian rupa agar efesiensi penggunannya maksimal dan secara ekonomis harga ransum menjadi murah ( $\mathrm{Scott}$ dan Dean, 1991).

Konsumsi ransum seekor itik akan menurun apabila diberi ransum dengan kandungan energi tinggi, apabila kandungan zat-zat makanan lainnya terutama protein tidak diperhatikan maka akan terjadi defisiensi yang berakibat buruk terhadap produktivitas. Tingkat konsumsi protein sangat ditentukan oleh tingkat konsumsi ransum, karena apabila itik mengkonsumsi ransum dalam jumlah yang lebih banyak maka akibatnya pada itik akan mengkonsumsi lebih banyak protein sehingga terjadi kelebihan protein didalam tubuh. Oleh sebab itu tingkat energi dan protein yang tepat akan menghasilkan produktivitas dan performa yang maksimal. Protein dan kandungan zat makanan lain yang terdapat pada ransum tidak dapat dicerna seluruhnya oleh unggas, untuk mencapai efisiensi ransum diperlukan cara agar protein yang digunakan dalam ransum dapat dicerna secara optimal, sehingga dapat memberikan pengaruh yang optimal terhadap produktivitas, salah satunya dengan penambahan probiotik.

Probiotik berfungsi membantu proses pencernaan unggas, agar lebih memudahkan pencernaan dan meningkatkan kapasitas daya cerna sehingga diperoleh nutrien yang lebih banyak untuk pertumbuhan maupun produksi (Ramia, 2000). Melalui bantuan pencernaan oleh enzim yang dihasilkan bakteri probiotik maka hal tersebut akan membatu penyerapan zat-zat makanan, sehingga ransum yang dikonsumsi banyak termanfaat untuk tubuh dibandingkan yang keluar memalui feses. Bakteri B. amyloliquefaciens bersifat dwifugsi dimana selain dia bisa digunakan sebagai inokulum fermentasi bakteri tersebut juga bisa digunakan sebagai probiotik. $B$. amyloliquefaciens efektif menurunkan kandungan serat kasar onggok (Wizna et al., 2009) dan dedak (Wizna et al., 2012). B. amyloliquefaciens dapat dijadikan sebagai probiotik karena bakteri tersebut memenuhi persyaratan yang diperlukan sebagai prboiotik, diantaranya adalah bakteri tersebut menghasilkan endospora tahan panas, mempunyai kemampuan untuk mendegradasi xylan dan karbohidrat, tumbuh dengan baik pada suhu $40^{\circ} \mathrm{C}$ dan $\mathrm{pH} 6$, tahan terhadap pasteurisasi dan mampu tumbuh pada larutan garam konsentrasi tinggi (10\%) (Wizna, 2007). B. amyloliquefaciens dapat bertahan di usus halus ayam ras petelur selama 32 hari dengan jumlah koloni $18 \times 10^{-7} \mathrm{CFU} /$ gram usus halus segar, menurunkan $0.9 \%$ konsumsi ransum dan meningkatkan $5.39 \%$ massa telur (Parawitan, 2009). Pemberian probiotik Bacillus amyloliquefaciens melalui air minum sebanyak 2000 ppm pada itik Pitalah umur 6 minggu menunrunkan konsumsi ransum dan meningkatkan efisiensi ransum lebih dari $15 \%$, meningkatkan total colony Bacillus 
sp dalam usus halus, dan menunrunkan pH usus halus (Zurmiati et al., 2017). Dari uraian diatas maka dilakuakan penelitian untuk menentukan imbangan energi dan protein dalam ransum itik Pitalah yang diberi probiotik Bacillus amyloliquefaciens terhadap pertumbuhan itik Pitalah.

\section{METODE}

Ternak yang digunakan adalah itik Pitalah yang berumur 1 hari (DOD) sebanyak 135 ekor yang diperoleh dari peternak itik di daerah Payakumbuh, Sumatera Barat, Indonesia. Kandang yang digunakan adalah kandang box yang terdiri dari 27 unit masingmasing ditempati oleh 5 ekor itik. Tiap unit kandang berukuran $80 \mathrm{~cm} \times 60 \mathrm{~cm} \times 60 \mathrm{~cm}$, untuk pemanasan anak itik digunakan lampu pijar 60 watt untuk tiap kotak sampai umur 3 minggu atau sampai pertumbuhan bulu dan untuk selanjutnya lampu pijar cukup dipasang pada malam hari saja.

Ransum disusun sendiri dari bahanbahan seperti jagung giling, dedak, tepung ikan, bungkil kedele, tepung tulang dan top mix. Ransum percobaan adalah perbedaan imbangan energi dan protein dalam ransum yaitu: level energi $(2800,2700$, dan 2600 $\mathrm{kkal} / \mathrm{kg}$ ) dan level protein $(18,17$, dan $16 \%$ ). Air minum diberikan secara ad libitum. Dosis pemberian probiotik Bacillus amyloliquefaciens 2000 ppm tiap perlakuan. Kandungan zat makanan (\%) dan energi metabolisme $(\mathrm{kkal} / \mathrm{kg})$ dapat dilihat pada Tabel 1 dan komposisi kandungan zat-zat makanan (\%) dan energi metabolisme (kkal/ $\mathrm{kg}$ ) ransum penelitian (berat kering udara) pada Tabel 2.

Metode penelitian yang digunakan dalam penelitian ini adalah metode eksperimen dengan menggunakan Rancangan Acak Kelompok (RAK) dengan pola faktorial $3 \times 3$ dengan 3 kelompok bobot badan sebagai ulangan. Perlakuan faktor A adalah 3 level energi metabolisme $(2800 \mathrm{kkal}, 2700 \mathrm{kkal}$, $2600 \mathrm{kkal}$ ) dan faktor B, 3 level protein kasar $(18 \%, 17 \%, 16 \%)$.

\section{HASIL DAN PEMBAHASAN}

\section{Konsumsi Ransum}

Tabel 3 menunjukkan bahwa interaksi antara level energi dan level protein berpengaruh sangat nyata $(\mathrm{P}<0,01)$ terhadap konsumsi ransum itik. Untuk mengetahui perbedaan antar perlakuan dilakukan Uji Jarak Berganda Duncan. Pada Tabel 3 terlihat kisaran konsumsi ransum itik Pitalah pada periode starter yaitu 4767.20 sampai 4901.70 g/ekor. Konsumsi pakan terus meningkat seiring dengan rendahnya energi dan protein dalam ransum. Konsumsi pakan itik tertinggi pada level energi $2600 \mathrm{kkal} / \mathrm{kg}$ dan protein

Tabel 1. Kandungan zat-zat makanan (\%) dan energi metabolisme (kkal/kg) bahan penyusun ransum penelitian (berat kering udara)

\begin{tabular}{lcrrrrc}
\hline \multirow{2}{*}{ Bahan pakan } & \multicolumn{5}{c}{ Zat-zat makanan dan energi metabolisme } \\
\cline { 2 - 7 } & PK (\%) & LK (\%) & SK (\%) & Ca (\%) & P (\%) & ME (kkal/kg) \\
\hline Jagung giling $^{\mathrm{c}}$ & 8,60 & 3,80 & 2,90 & 0,01 & 0,13 & 3329,00 \\
Dedak $^{\mathrm{c}}$ & 10,00 & 13,50 & 15,00 & 0,07 & 0,21 & 1670,00 \\
T.Ikan $^{\mathrm{b}}$ & $36,56^{\mathrm{d}}$ & 2,83 & 3,05 & 3,11 & 1,31 & 2820,00 \\
B.Kedelai $^{\mathrm{b}}$ & 40,56 & 2,68 & 5,71 & 1,29 & 0,69 & 2540,00 \\
T. tulang $^{\mathrm{b}}$ & - & - & - & 26,00 & 13,00 & - \\
Top Mix $^{\mathrm{b}}$ & - & - & - & 5,38 & 1,44 & - \\
\hline
\end{tabular}

Sumber: a. Amrullah (2003)

b. Nuraini (2008)

c. Yesirita (2010)

d. Zurmiati et al. (2017) 
Tabel 2. Komposisi, kandungan zat-zat makanan (\%) dan energi metabolisme (kkal/kg) komposisi bahan penelitian.

\begin{tabular}{|c|c|c|c|c|c|c|c|c|c|}
\hline \multirow{2}{*}{ Bahan pakan } & \multicolumn{9}{|c|}{ Komposisi bahan perlakuan } \\
\hline & E1P1 & E1P2 & E1P3 & E2P1 & E2P2 & E2P3 & E3P1 & E3P2 & E3P3 \\
\hline Jagung (\%) & 52,5 & 55,0 & 56,5 & 48,0 & 50,5 & 52,0 & 42,5 & 45,5 & 47,0 \\
\hline Dedak $(\%)$ & 18,0 & 19,0 & 19,5 & 22,0 & 23,0 & 24,0 & 28,0 & 27,0 & 28,0 \\
\hline T. Ikan (\%) & 14,0 & 12,0 & 11,5 & 14,0 & 13,0 & 11,0 & 14,0 & 12,0 & 10,5 \\
\hline B. Kedele (\%) & 14,5 & 12,5 & 11,0 & 14,5 & 12,0 & 11,5 & 14,0 & 13,5 & 12,5 \\
\hline T. Tulang (\%) & 0,5 & 1,0 & 1,0 & 1,0 & 1,0 & 1,0 & 1,5 & 1,5 & 1,5 \\
\hline tpo $\operatorname{mix}(\%)$ & 0,5 & 0,5 & 0,5 & 0,5 & 0,5 & 0,5 & 0,5 & 0,5 & 0,5 \\
\hline TOTAL & 100 & 100 & 100 & 100 & 100 & 100 & 100 & 100 & 100 \\
\hline PK (\%) & 18,40 & 17,02 & 16,43 & 18,42 & 17,36 & 16,41 & 18,37 & 17,35 & 16,47 \\
\hline LK (\%) & 5,21 & 5,33 & 5,40 & 5,58 & 5,71 & 5,84 & 6,17 & 6,08 & 6,20 \\
\hline SK (\%) & 5,48 & 5,22 & 5,54 & 5,95 & 6,00 & 6,10 & 6,66 & 6,51 & 6,60 \\
\hline $\mathrm{Ca}(\%)$ & 0,80 & 0,84 & 0,81 & 0,93 & 0,87 & 0,80 & 0,93 & 0,99 & 0,93 \\
\hline $\mathrm{P}(\%)$ & 0,46 & 0,49 & 0,48 & 0,53 & 0,50 & 0,48 & 0,53 & 0,57 & 0,55 \\
\hline ME (kkal/kg) & 2811,43 & 2804,15 & 2810,24 & 2728,42 & 2736,65 & 2734,18 & 2632,83 & 2646,90 & 2645,83 \\
\hline
\end{tabular}

Keterangan: Dihitung berdasarkan Tabel 1.

$16 \%$. Hal ini disebabkan kandungan nutrisi yang berbeda yaitu adanya perbedaan tingkat energi dan protein. Semakin rendah energi dan protein yang diberikan maka semakin tinggi konsumsi ransum karena ternak akan terus makan sampai energinya terpenuhi. Apabila kebutuhan energi ternak sudah tercukupi maka konsumsi akan sedikit dan sebaliknya (Rasyaf, 2002).

Pada perlakuan energi $2800 \mathrm{kkal} / \mathrm{kg}$ dan protein $18 \%$, terlihat konsumsi pakan terendah, namun secara statistik tidak berbeda nyata terhadap perlakuan energi $2800 \mathrm{kkal} /$ $\mathrm{kg}$ dan protein $17 \%$, energi $2800 \mathrm{kkal} / \mathrm{kg}$ dan protein $16 \%$, energi $2700 \mathrm{kkal} / \mathrm{kg}$ dan protein $18 \%$, dan energi $2700 \mathrm{kkal} / \mathrm{kg}$ dan protein $17 \%$. Hal ini disebabkan adanya bantuan dari kerja enzim yang dihasilkan $B$. amyloliquefaciens sebagai probiotik dalam saluran pencernaan. $B$. amyloliquefaciens, menghasikan enzimn $\alpha$-amylase, $\alpha$-acetolactate decarboxylase, $\beta$-glucanase, maltogenic amylase, urease, protease, xylanase, chitinase, phytase, cellulase, hemicellulase, dan lipase (Luizmera, 2005; Kim et al., 1998; Wizna et al., 2007; Selvamohan et al., 2012). Probiotik dapat memperbaiki saluran pencernaan dan meningkatkan kecernaan pakan, yaitu dengan cara menekan bakteri patogen dalam saluran pencernaan sehingga mendukung perkembangan bakteri yang menguntungkan yang membantu penyerapan zat-zat makanan (Kompiang, 2002). Luas permukaan usus untuk menyerap nutrien lebih luas pada ayam yang memperoleh probiotik Bacillus $\mathrm{sp}$ dibandingkan dengan yang tidak mendapat probiotik (Sjofjan, 2003). Probiotik dapat mengubah pergerakan mucin dan populasi mikroba didalam usus halus ayam, sehingga keberadaannya dapat meningkatkan fungsi dan kesehatan usus, memperbaiki komposisi mikroflora pada sekum, serta meningkatkan penyerapan zat makanan (Mountzouris et al., 2010). Pemberian probiotik $B$. amyloliquefaciens melalui air minum pada itik Pitalah umur 6 minggu dapat menurunkan konsumsi pakan, dan meningkatkan efisiensi ransum hampir $15 \%$, meningkatkan total coloni Bacillus sp dalam usus dan menurunkan pH usus halus (Zurmiati et al., 2017).

Rasio energi-protein ransum terbaik pada penelitian ini adalah 158.82. Sesuai dengan yang dilaporkan Susanto (2004) bahwa kisaran rasio ideal energi-protein yaitu antara 145 sampai dengan 160. Rataan konsumsi ransum itik Pitalah pada perlakuan energi $2700 \mathrm{kkal} / \mathrm{kg}$ dan protein $17 \%$ yang diberi probiotik $B$. amyloliquefaciens selama 8 minggu penelitian adalah 4776,73 g/ekor. Hasil penelitian ini lebih rendah dibandigkan dari hasil penelitian Sudiyono dan Purwatri (2007) bahwa konsumsi rata-rata itik jantan 
Tabel 3. Rataan konsumsi ransum, pertambahan bobot badan dan konversi ransum itik Pitalah yang diberi probiotik Bacillus amyloliquefaciens dengan imbangan energi dan protein ransum yang berbeda selama penelitian.

\begin{tabular}{ccccc}
\hline $\begin{array}{c}\text { Energi } \\
(\mathrm{kkal} / \mathrm{kg})\end{array}$ & $\begin{array}{c}\text { Protein } \\
(\%)\end{array}$ & $\begin{array}{c}\text { Konsumsi ransum } \\
(\mathrm{g} / \mathrm{ekor})\end{array}$ & $\begin{array}{c}\text { Pertambahan bobot badan } \\
(\mathrm{g} / \mathrm{ekor})\end{array}$ & $\begin{array}{c}\text { Konversi } \\
\text { ransum }\end{array}$ \\
\hline \multirow{2}{*}{2800} & 18 & $4756,00^{\mathrm{c}}$ & $1083,26^{\mathrm{a}}$ & $4,44^{\mathrm{c}}$ \\
& 17 & $4764,20^{\mathrm{c}}$ & $1053,95^{\mathrm{a}}$ & $4,59^{\mathrm{c}}$ \\
& 16 & $4786,44^{\mathrm{b}}$ & $873,77^{\mathrm{b}}$ & $5,52^{\mathrm{b}}$ \\
\hline \multirow{2}{*}{2700} & 18 & $4771,98^{\mathrm{bc}}$ & $1049,39^{\mathrm{a}}$ & $4,62^{\mathrm{c}}$ \\
& 17 & $4776,73^{\mathrm{bc}}$ & $1037,66^{\mathrm{a}}$ & $4,69^{\mathrm{c}}$ \\
& 16 & $4830,33^{\mathrm{a}}$ & $828,39^{\mathrm{bc}}$ & $5,91^{\mathrm{ab}}$ \\
\hline \multirow{2}{*}{2600} & 18 & $4860,27^{\mathrm{e}}$ & $821,15^{\mathrm{bc}}$ & $5,93^{\mathrm{ab}}$ \\
& 17 & $4823,53^{\mathrm{a}}$ & $767,22^{\mathrm{bc}}$ & $6,30^{\mathrm{a}}$ \\
& 16 & $4901,70^{\mathrm{d}}$ & $708,65^{\mathrm{c}}$ & $6,92^{\mathrm{d}}$ \\
\hline
\end{tabular}

Keterangan: Superskrip yang berbeda menunjukan pengaruh berbeda nyata $(\mathrm{P}<0,05)$ antar perlakuan.

lokal yang mendapat perlakuan feed additive dalam pakan berkisar antara 6.502,8-6.636 gram atau 108,38-110,60 gram per ekor per hari. Tingkat konsumsi ransum tiap perlakuan denganenergi-protein berbeda sangatberagam, sejalan dengan pendapat Hardjosworo dan Rukmiasih (2000) bahwa kemampuan itik lokal jantan untuk mengkonsumsi ransum sampai umur 8 minggu umumnya masih beragam.

\section{Pertambahan Bobot Badan}

Hasil analisis ragam menunjukkan bahwa interaksi antara level energi dan level protein berpengaruh sangat nyata $(\mathrm{P}<0,01)$ terhadap pertambahan bobot badan itik. Untuk mengetahui perbedaan antar perlakuan dilakukan Uji Jarak Berganda Duncan. Pada Tabel 3 terlihat kisaran pertambahan bobot badan itik Pitalah selama penelitian yaitu 1069,93 sampai 755,32 g/ekor. Pertambahan bobot badan terus menurun seiring dengan rendahnya energi dan protein dalam ransum. Pada perlakuan energi $2800 \mathrm{kkal} / \mathrm{kg}$ dan protein $18 \%$, terlihat pertambahan bobot badan tertinggi, tetapi secara statistik tidak berbeda nyata dengan perlakuan energi 2800 $\mathrm{kkal} / \mathrm{kg}$ dan protein $17 \%$, energi $2800 \mathrm{kkal} /$ $\mathrm{kg}$ dan protein $16 \%$, energi $2700 \mathrm{kkal} / \mathrm{kg}$ dan protein $18 \%$, energi $2700 \mathrm{kkal} / \mathrm{kg}$ dan protein $17 \%$, namun saat permberian energi $2700 \mathrm{kkal} / \mathrm{kg}$ dan protein $16 \%$, energi 2600 $\mathrm{kkal} / \mathrm{kg}$ dan protein $18 \%$, energi $2600 \mathrm{kkal} /$ $\mathrm{kg}$ dan protein $17 \%$, dan energi $2600 \mathrm{kkal} / \mathrm{kg}$ dan protein $16 \%$ dalam ransum menunjukan hasil yang berbeda nyata $(\mathrm{P}<0.05)$ terhadap pertambahan bobot badan. Hal ini disebakan imbangan energi dan protein dalam ransum sudah jauh berbeda, sehingga kemapuan $B$. amyloliquefaciens sebagai probiotik tidak mampu lagi memperbaiki saluran pencernaan dan meningkatkan kecernaan pakan. Sejalan dengan pendapat Anggorodi (1985) bahwa tujuan ternak mengkonsumsi ransum adalah untuk mempertahankan hidup, meningkatkan bobot badan, dan untuk berproduksi, oleh karena itu ransum yang mengandung nutrisi yang kurang memadai akan menghasilkan defisiensi sehingga mengganggu bobot badan. Hal ini juga sejalan dengan yang dilaporkan oleh Pesti (2009) yang menyatakan bahwa level protein dalam pakan merupakan pembatas dalam pertumbuhan dan efisiensi penggunaan pakan.

Rataan pertambahan bobot badan itik Pitalah pada perlakuan energi $2700 \mathrm{kkal} /$ $\mathrm{kg}$ dan protein $17 \%$ yang diberi probiotik $B$. amyloliquefaciens selama 8 minggu penelitian adalah 1037,66 g/ekor, hasil penelitian ini lebih tinggi dari yang dilaporkan oleh Sobri (2005) bahwa pertambahan bobot badan itik lokal umur $4-9$ minggu rata-rata 1011,77 \pm $49,19 \mathrm{~g} /$ ekor. 


\section{Konversi Ransum}

Hasil analisis ragam menunjukkan bahwa interaksi antara level energi dan level protein berpengaruh sangat nyata $(\mathrm{P}<0,01)$ terhadap konversi ransum itik. Untuk mengetahui perbedaan antar perlakuan dilakukan Uji Jarak Berganda Duncan. Pada Tabel 3 terlihat kisaran konversi ransum itik Pitalah selama penelitian yaitu 4,52 sampai 6,50 . Konversi ransum terus meningkat seiring dengan rendahnya energi dan protein dalam ransum. Konversi ransum tertinggi terdapat pada perlakuan level energi $2600 \mathrm{kkal} / \mathrm{kg}$ dan protein $16 \%$. Konversi ransum terendah terdapat pada perlakuan energi $2800 \mathrm{kkal} / \mathrm{kg}$ dan protein $18 \%$, namun secara statistik tidak berbeda nyata terhadap perlakuan energi 2800 $\mathrm{kkal} / \mathrm{kg}$ dan protein $17 \%$, energi $2800 \mathrm{kkal} /$ $\mathrm{kg}$ dan protein $16 \%$, energi $2700 \mathrm{kkal} / \mathrm{kg}$ dan protein $18 \%$, dan energi $2700 \mathrm{kkal} / \mathrm{kg}$ dan protein $17 \%$. Hal ini disebabkan pada konsumsi ransum dan pertambahan bobot badan juga tidak berpengaruh dengan pemberian energi sampai $2700 \mathrm{kkal} / \mathrm{kg}$ dan protein $17 \%$, namun ketika energi sudah di bawah $2700 \mathrm{kkal} / \mathrm{kg}$ dan protein dibawah $17 \%$ konversi ransum sudah tidak efisien lagi. Hal ini disebabkan kandungan nutrisi yang jauh berbeda yaitu adanya perbedaan tingkat energi dan protein dalam ransum. Semakin rendah energi dan protein yang diberikan maka semakin tinggi konsumsi ransum karena ternak akan terus makan sampai energinya terpenuhi.

Efisiensi penggunaan ransum saling berkaitan dengan konsumsi ransum dan pertambahan bobot badan, tetapi konsumsi ransum yang tinggi tidak selalu diikuti dengan efisiensi penggunaan ransum yang tinggi. Efisiensi ransum adalah kemampuan ransum yang dikonsumsi dalam satu waktu tertentu untuk menghasilkan berat badan seekor ternak dalam waktu yang sama (Yamin, 2008). Semakin kecil nilai konversi ransum maka efisiensi ransum semakin baik, sedangkan semakin besarnya nilai konversi ransum maka efisiensi ransum semakin kecil. Konversi ransum dapat digunakan sebagai gambaran efisiensi produksi. Angka konversi ransum yang kecil berarti banyaknya ransum yang digunakan untuk menghasilkan satu kilogram daging semakin sedikit (Kartasudjana dan Supriyatna, 2005). Hasil terbaik dari penelitian adalah pada imbangan energi 2700 $\mathrm{kkal} / \mathrm{kg}$ dan protein $17 \%$ dalam ransum. Hasil penelitian ini tidah jauh berbeda dengan yang dilaporkan oleh Alyandari (2014), bahwa tingkat energi $2700 \mathrm{kkal} / \mathrm{kg}$ dan protein $16 \%$ menghasilkan performa itik Rambon jantan terbaik pada fase pertumbuhan (umur itiknya 8 minggu).

\section{KESIMPULAN}

Berdasarkan hasil penelitian dapat disimpulkan bahwa pemberian 2000 ppm probiotik Bacillus amyloliquefaciens, dengan imbangan energi dan protein ransum yang berbeda dapat menurunkan kebutuhan energi ransum itik sebesar 3,57\% dan menurunkan kebutuhan protein sebesar $5,56 \%$ dengan imbangan energi $2700 \mathrm{kkal}$ dan protein $17 \%$ dalam ransum.

\section{DAFTAR PUSTAKA}

Alyandari, N. R., S. Wahyuni dan Abun. 2014. Performa itik rambon jantan fase pertumbuhan pada pemberian ransum dengan kandungan energi - protein berbeda. Universitas padjajaran, nomor 1.

Amrullah, I. K. 2003. Nutrisi Ayam Petelur. Cetakan Pertama. Lembaga satu Gunung Budi. Bogor.

Anggorodi, R. 1985. Kemajuan Mutakhir dalam Ilmu Makanan Ternak Unggas. Cetakan Pertama. Universitas Indonesia. Jakarta.

Hardjosworo, P. S. dan Rukmiasih. 2000. Meningkatkan Produksi Daging Unggas.Penebar Swadaya. Jakarta.

Kartasudjana, R. dan E. Suprijatna. 2005. Manajemen Ternak Unggas. Penebar Swadaya. Jakarta. 
[Kementan] Keputusan Menteri Pertanian Republik Indonesia, 2011. Pentapan Rumpun Itik Pitalah. Nomor 2923/kpts/ ot.140/6/2011. Jakarta.

Kim, Y. O., J. H. Yu, and T. K. Oh. 1998. Cloning of the thermostable phytase gene (phy) from Bacillus sp. DS11 and its overexpression in Escherichia coli, FEMS microbiol. 162:185-191.

Kompiang, I. P. 2002. Pengaruh ragi Saccharomyces cerevisiae dan ragi laut sebagai Pakan Imbuhan Probiotik terhadap kinerja unggas. JITV 7(1):1821.

Luizmera. 2005. USD Recomendar esta Pagina, Luizmera.com/enzimas.htm

Mountzouris K. C., P. Tsitrsikos, I. Palamidi, A. Arvaniti, M. Mohnl, G. Schatzmayr and K. Fegeros. 2010. Effects of probiotic inclusion levels in broiler nutrition on growth performance, nutrient digestibility, plasma immunoglobulins, and cecal microflora composition. Poult. Sci. 89: 58-67.

Nuraini, Sabrina dan S. A. Latif. 2008. Performa ayam dan kualitas telur yang menggunkaan ransum mengandung onggok fermentasi dengan neurospora crassa. Jurnal Media Peternakan. 31 (3): 195-202.

Parawitan, M. 2009. Pengaruh pemberian probiotik B. amyloliquefaciens terhadap populasinya di usus halus sehubungan efektivifitas ransum ayam ras petelur.

Pesti, G. M., T. S. Whiting and L. S. Jensen. 2009. The effect of crumbling on the relationship between dietery density and chick growth, feed efficiency and abdominal fat pad weights. Poult. Sci., 62:490-494.

Ramia, I. K. 2000. Suplementasi ProbiotikDalam Ransum Berprotein Rendah Terhadap Penampilan Itik Bali. Majalah Ilmiah Peternakan Vol.3 No.3. Yogyakarta.

Rasyaf. 2002. Bahan Makanan Unggas di
Indonesia. Cetakan IX. Kanisius, Jakarta.

Scott, M. L. and W. F. Dean.1991. Nutrition and Management of Ducks. M.L. Scott of Ithaca. New York.

Selvamohan. T, V. Ramadas and T. A. Sathya. 2012. Optimization of Lipase Enzyme Activity Produced by Bacillus amyloliquefaciens Isolated From Rock Lobster Panlirus Homarus. Modern Engineering Research (IJMER) Journal. November -December. 2012 pp-4231-4234. Volume 2, Number 6 ISSN: 2249-6645.

Sjofjan, O. 2003. Study of Probiotics (Aspergillus niger and Bacillus sp) as Rations Additive and Implications on Intestinal Microflora and Performances Production of Laying Hens. Disertasi. Universitas Padjadjaran. Bandung.

Sobri, M. 2005. Pengaruh sumber energi dan asam lemak ransum terhadap kinerja produksi dan perlemakan tubuh itik Mojosari jantan. Tesis. Program Pascasarjana. Universitas Gadjah Mada. Yogyakarta.

Sudiyono dan T. H. Purwatri. 2007. Pengaruh penambahan enzim dalam ransum terhadap persentase karkas dan bagianbagian karkasitik lokal jantan. J. Pengemb. Petern. Tropis. 32:270-277.

Suharno, B. dan K. Amri. 2000. Beternak Itik Secara Intensif. Penebar Swadaya. Jakarta.

Susanto, R. S. 2004. Pengaruh Perbedaan Tingkat Protein Dalam Ransum Terhadap Produktivitas Itik Indian Runner. Skripsi. Fakultas Pertanian Universitas Sebelas Maret. Surakarta: hal 32-33.

Wizna, H. Abbas, Y. Rizal, A. Dharma dan I. P. Kompiang. 2007. Selection and identification of cellulase-producing bacteria isolated from the litter of mountain and swampy forest. Microbiology Indonesia Journal, December 2007, P 135-139 Volume 1,

Pengaruh Imbangan Energi dan ... (Zurmiati et al.) 
Number 3 ISSN 1978-3477.

Wizna, H. Abbas, Y. Rizal, A. Dharma, and I. P. Kompiang. 2009. Improving the quality of tapioca by-products (onggok) as poultry feed through fermentation by Bacillus amyloliquefaciens. J. Appl. Ind. Biotechnol. Trop. Reg. 2:1-5.

Wizna, H. Abbas, Y. Rizal, A. Djulardi, and H. Muis. 2012. The effect of supplementation of micro nutrient on nutrient rice bran which fermented by Bacillus amyloliquefaciens. Pakistan J. Nutr. 11:439-443.

Yamin, M. 2008. Pemanfaatan Ampas Kelapa dan Ampas Kelapa Fermentasi dalam Ransum Terhadap Efisiensi Ransum dan Income Over Feed Cost Ayam Pedaging. Journal Agroland 15 (2) : 135-139, Juni 2008 ISSN hal : 1854641.

Yesirita N. 2010. Pengaruh penggunaan kapang Trichoderma viride terhadap kandungan $\beta$-karoten pada pembiakan beberapa media tumbuh bahan pakan unggas. Laporan Akhir Penelitian Dosen Muda. Kopertis Wil. Padang.

Zurmiati, Wizna, H. Abbas, M. E. Mahata and R. Fauzano. 2017. Effect of Bacillus amyloliquefaciens as a probiotic on growth performance parameters of Pitalah ducks. Int. J.Poult.Sci., 16 (4): 147-153. 